\title{
燃料電池動力源の深海巡航探査機 「うらしま」
}

Cruising Autonomous Underwater Vehicle “URASHIMA” Powered with Fuel Cell

\section{執筆者プロフィール}

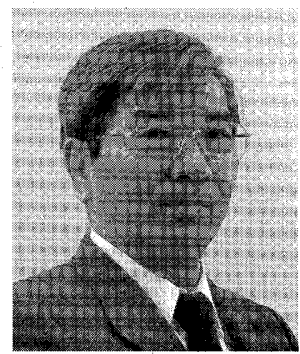

青木 太郎

Taro AOKI

1947年5月生まれ

1972年電気通信大学電気通信学部通信工学 科卒業

目として行っている業務・研究

・海洋工学, 海洋調查機器の研究開発

四所属学会および主な活動

電気学会, 日本機械学会

\section{口勤務先}

(独) 海洋研究開発機構 海洋工学センター 海洋技術研究開発プログラム プログラム・ ディレクター

（干 237-0061 横須賀市夏島 2-15／

E-mail : aokit@jamstec.go.jp)

\section{1. はじめに}

深海巡航探查機「うらしま」は, 2004 年 6 月, 駿河湾で実施した性 能試験において，世界初の燃料電池を 用いて $220 \mathrm{~km}$ という連続長距離航 走に成功し，本年2月に317km の 世界最長記録を樹立した（図1)。

「うらしま」の最大使用深度は $3500 \mathrm{~m}$ である. この高水圧のかか る深海で用いるため, 燃料電池を密閉 空間で発電する必要がある．このため 閉鎖式燃料電池という最新鋭動力源を 世界に先駆けて開発し搭載している. 蜘料電池を用いた水中探査機は他に例 がなく，世界的な記録である。

燃料である水素は，新たに唄蔵効率 の高い水素吸蔵合金を開発し，これに
蓄えた。自動車などに用いられている 高圧ボンベと異なり，安全に用いるこ とができる，また220km, 230km を航走した際，最新技術である金属セ パレータを用いたこの燃料電池の工ネ ルギー効率は 54\% を超え，世界トッ プレベルの高性能を示した.

深海巡航探査機「うらしま」は，機 体內にコンピュータと, 誤差が極少の リングレーザジャイロ慣性航法装置を 内蔵し，あらかじめインストールされ たシナリオに従って自分の位置を計算 しながら自律して自動航走する，電子 技術，材料技術，燃料電池技術などの 我が国の最新技術を結集した長距離航 走型の“海洋ロボット”である，海底
地震域の深海底調査や，地球温暖化現 象の調査，資源調査などに役立てるこ とを目的としている

さらに，10 倍の航続距離を航走可 能な「うらしま2号」を構想してい る.航続距離 $3000 \mathrm{~km}$ の能力を有 すると, 北極海横断観測調查や，支援 母船なしに港から自動出港して経済水 域最遠端までをほぼ往復する調査が可 能となるなど，海洋調査を大きく変え ることができる（図2）

\section{2. 要素技術}

現在のように開発ブームの状況でな い1989 年から燃料電池の研究開発

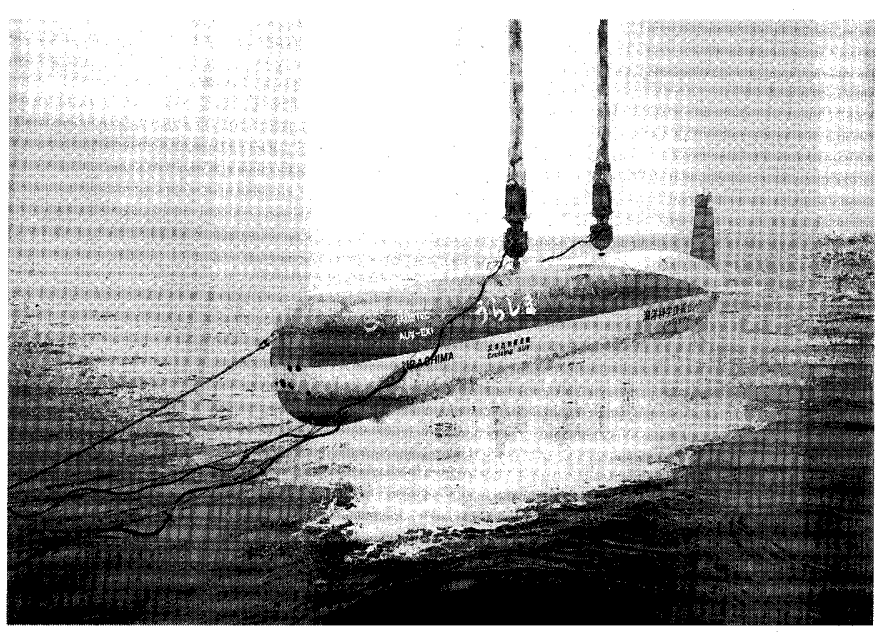

図 1 支援母船「よこすか」に揚収される「うらしま」

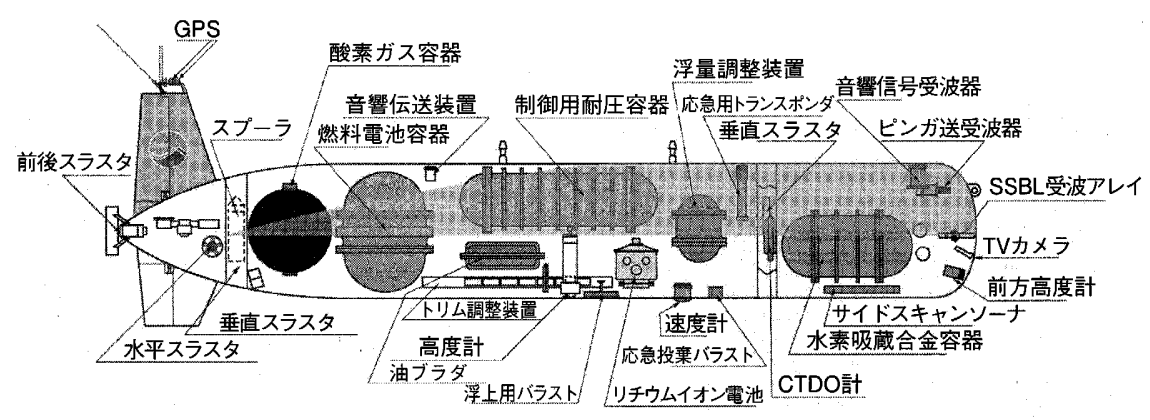

図 2 「うらしま」構造図 
を始め, 1993 年に 1 kW 出力の閉鎖 式固体高分子電解質膜型燃料電池 (PEFC) の試作機を開発した。その ことを基礎にさらに研究を続け性能の 向上を求めた. 1998 年に本探査機 の開発が認められ，燃料電池を動力源 に,コンピュータを駆使して自律航走 する深海巡航探査機の研究開発に着手 した．燃料電池は探査機を巡航速度 3 ノット (注) (最大速力 4 ノット) で航走 可能な $4 \mathrm{~kW}$ タイプである.うねりの 激しい荒天時でも確実に発電し，ガス 漏れを発生させなしことが必要で, こ のために燃料電池の心臓部であるス タックの高性能化が重要な課題であつ た、スタックの構成部品であるセパ レ一タの材質は，一般的にカ一ボンが 用いられている。 カ一ボンでは物理的 な外力に弱く，割れてガスが漏れる事 態を防げないことや，塑性なため薄く することに限界があった．このことの 解決策として，セパレータに金属のス テンしスを採用し，2mm 程度の厚み にガスを通す精密な溝加工を施して， 上記の問題点を克服した. 1 セルが $3 \mathrm{~mm}$ 以下と極薄に仕上がっており， 80 セルを積層して約 64 ボルト 40 アンペアの電気を発生するスタックを 開発した（図3）。これを2個直列接 続し 128 ボルト40アンペアとし, 「うらしま」に搭載した。ガス漏れは 100 時間を超える連続耐久試験でも 全く発生せず, コンパクトで高性能, かつ安全な燃料電池システムが出来上 がった．機体内のタンクに収納してい る燃料電池は, 密閉された耐水圧容器 内で，ほぼ大気圧に近い状態で発電を 行う. 生成水を, 水深 $3500 \mathrm{~m}$, す なわち 350 気圧の環境下に放出する には多大なエネルギーを必要とする。 また，探査機は，飛行船と同様に水中 でほぼ中性浮力の状態に保たれてい る。機体外に，生成水を放出すると浮 カバランスが崩れ，浮き勝手になって しまう。これを修正するために海水を 機体内に取り込むといつた矛盾した制 御を行わねばならない，このため，本 探査機では，生成水を機体内のタンク に溜める方法を採用した（図4）

燃料である水素は，当初，350気

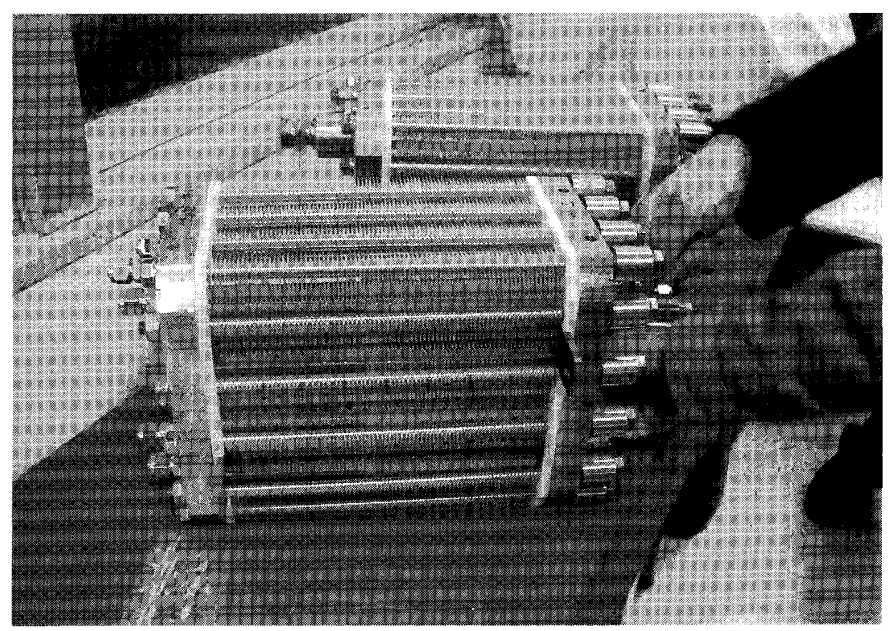

図 3 発電スタック $2 \mathrm{~kW} \times 2$ 個

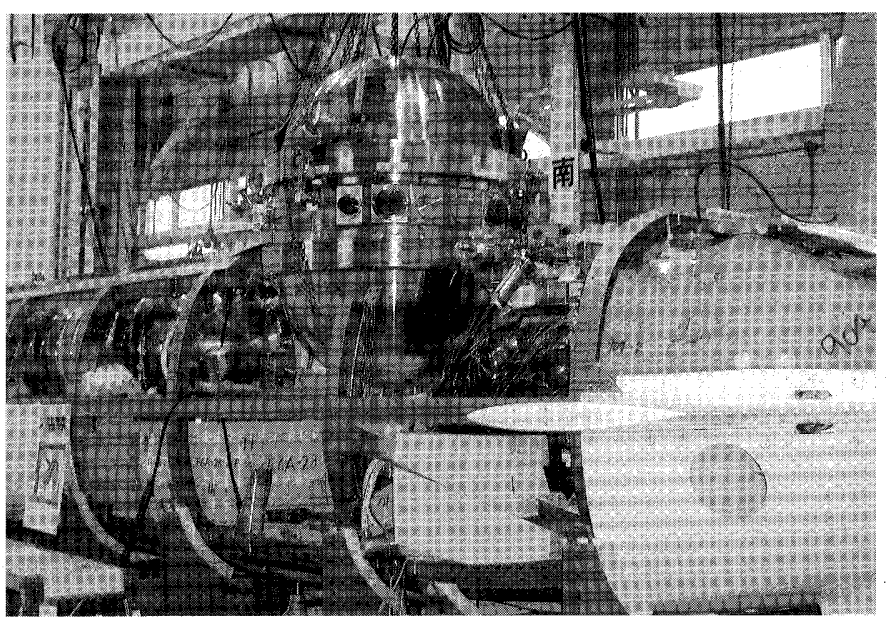

図 4 燃料電池を収納したチタン合金製の耐水圧容器

圧のガスタンクに貯蔵する方式で設計 を進めていた，しかし安全性の面から 問題があるため解決しなければならな い課題となっていたが，別途進めてい た金属合金に水素を貯蔵する研究が実 用化できるレベルになり，この方式を 採用した，約 $0.1 \mathrm{~m}^{3}$ の水素吸蔵合金 に大気圧で $110 \mathrm{~m}^{3}$ の水素を貯蔵する ことができた，水素を吸蔵するには約 $10^{\circ} \mathrm{C}$ に冷やし，排出するには約 $50^{\circ} \mathrm{C}$ に暖めるという温度制御で管理でき る. $50^{\circ} \mathrm{C}$ は作為的に加温しなければ成 立しない温度であるから，可燃ガスで ある水素を安全に貯蔵できる。

探査機が自律して長時間航走するに は，高精度の慣性航法装置が必要であ る，GPSを使用できる陸上とは異な り，海水中では自己の位置を知るため の他律的な仕組みがない．このため慣 性航法装置が重要な装置となるが，こ の心臓部となるジャイロに，誤差 0.1 海里／時という世界でもトップレベル
の慣性航法装置を開発し搭載した。こ の装置とドップラ流向流速計，そして コンピュータを駆使することで，50 時間で誤差 $10 \mathrm{~km}$ 以内と，従来に比 べ格段に小さな誤差で航走することが 可能となつた.

\section{3. おわりに}

以上のように深海巡航探査機「うら しま」が長時間, 長距離を自律して航 走できたのは，多くの技術課題を長年 にわたり研究し，解決してきたことの 結果である。.また，深海巡航探査機 「うらしま」が，自然科学や，資源調 査，国家セキュリティの方面に広く活 用されることはもとより, 燃料電池技 術，ジャイロ技術，自律制御システム などの要素技術は先進的な技術であ り，他のロボット産業，自動車産業， 宇宙産業などへの応用や，新しい産業 創出の芽となることを期待している。 